\author{
Aleksandra Luberda \\ Uniwersytet Jagielloński \\ aleksandra.luberda7@gmail.com
}

\title{
Józef Łobodowski ponad granicami
}

\author{
(Śladami pisarza. Józef Łobodowski w Polsce i w Hiszpanii, \\ red. G. Bąk, L. Siryk, E. Łoś, Wydawnictwo Uniwersytetu \\ Marii Curie-Skłodowskiej, Lublin 2016, ss. 398)
}

Józef Łobodowski Across the Borders

Tom Śladami pisarza. Józef Łobodowski w Polsce i w Hiszpanii jest w znacznej części owocem sympozjum naukowego „Józef Łobodowski (1909-1988): un poeta polaco y madrileño", które odbyło się w październiku 2014 roku w Instytucie Filologii Romańskiej, Filologii Słowiańskiej i Językoznawstwa Ogólnego na Wydziale Filologicznym Uniwersytetu Complutense; współorganizatorem był Instytut Kultury Polskiej w Madrycie. Jest to zbiór interdyscyplinarny, opublikowane w nim szkice poruszają zarówno problemy stricte literaturoznawcze, na przykład zagadnienia poetyki i języka utworów Józefa Łobodowskiego, jak i dotyczą jego losów jako emigranta politycznego w Madrycie. Uczeni z różnych ośrodków naukowych dzielą się wynikami swoich kwerend archiwalnych czy antropologiczno-kulturowych oraz wnikliwą i drobiazgową lekturą twórczości Łobodowskiego, skoncentrowaną wokół takich kręgów tematycznych, jak miłość poety do Ukrainy, inspiracje literaturą hiszpańską czy ślady pamięci o rodzinnym Lublinie, szczególnie w liryce pisarza.

Tom ten nie ma charakteru wyłącznie naukowego - zakres tematyczny jest bardzo szeroki, znajdują się w nim również artykuły biograficzne i wspomnieniowe. Zawiera teksty bliskich poety - rodziny i przyjaciół, które pozwalają poznać Józefa Łobodowskiego nie tylko jako twórcę i publicystę, ale także jako przyjaciela i nauczyciela, ważną figurę Polonii madryckiej.

Powojenne losy pisarza, status emigranta politycznego oraz działalność w Radiu Wolna Europa i Radiu Madryt przyczyniły się do odcięcia Łobodowskiego od polskiej publiczności na wiele lat. Jego twórczość wciąż pozostaje niedoczytana i niedoceniona $\mathrm{w}$ kraju pomimo prac na jej temat pojawiają- 
cych się na rynku wydawniczym od lat dziewięćdziesiątych. Książki Ireny Szypowskiej Eobodowski. Od "Atamana Łobody” do "Seniora Lobo" czy Ludmiły Siryk Naznaczony Ukraina: o twórczości Józefa Eobodowskiego niewątpliwie przygotowały grunt dla kolejnych badaczy twórczości lubelsko-madryckiego poety. Zbiór szkiców Śladami pisarza... jest zatem kolejnym krokiem mającym na celu wprowadzenie poety do panteonu literatury polskiej i światowej. Współpraca międzynarodowych ośrodków, nie tylko uniwersyteckich, ale także na przykład Muzeum Józefa Czechowicza w Lublinie, ma zaowocować odświeżeniem pamięci o poecie i wzrostem zainteresowania jego życiem i twórczością. Ważną częścią spuścizny Łobodowskiego są przekłady poezji hiszpańskiej na język polski. Chcąc poznać dogłębnie kulturę kraju, w którym przyszło mu żyć przeszło 50 lat, czytał tamtejszych poetów, od dawnych po jemu współczesnych, oraz dokonywał doskonałych przekładów, niestety nigdy niewydanych. Niewielka próbka tej działalności translatorskiej zamieszczona w aneksie tomu daje nam przedsmak talentu Łobodowskiego również jako tłumacza.

Artykuły, które znalazły się w tomie, cechuje duża rozpiętość tematyczna, ale wszystkie w jakiś sposób koncentrują się wokół centralnej postaci Łobodowskiego. W pierwszej części tomu możemy zapoznać się z kolejami życia poety z perspektywy badacza-biografisty. Grzegorz Bąk w eseju Józef Łobodowski en España opisuje wojenne losy pisarza, które doprowadziły go po tułaczce i okresie odosobnienia w więzieniu w Figueras do stolicy Hiszpanii, Madrytu. Opisuje nagłą fascynację pisarza Hiszpanią, decyzję o osiedleniu się w tym kraju oraz późniejszą, aktywną i wieloletnią pracę, między innymi w czasopiśmie polonijnym skierowanym do hiszpańskiego odbiorcy „Polonia. Revista Ilustrada”. Publikował również w paryskiej „Kulturze” i londyńskich „Wiadomościach", pracował - jak wspomniałam - w Radiu Madryt przy tworzeniu polskiej sekcji, współpracował też z oddziałem rosyjskim. Jego kontakty z innymi twórcami polskimi przebywającymi na emigracji w Londynie czy Stanach Zjednoczonych były sporadyczne, utrudnione przez porywczy i niestały charakter Łobodowskiego, który nieregularnie odpisywał na listy. Cieszył się wśród niektórych z nich doskonałą opinią utalentowanego literata. Takie informacje przekazuje Nina Taylor-Terlecka w swoim eseju W oczach jednego krytyka - gtos Tymona Terleckiego. Przywołuje ona korespondencję swojego męża z Kazimierzem Wierzyńskim pokazującą niezmienne zainteresowanie i troskę o los Łobodowskiego, którego zresztą uważa za twórcę wyższej rangi niż na przykład Czesława Miłosza. Poezję Łobodowskiego omawiał Tymon Terlecki na falach Radia Wolna Europa, entuzjastyczne przyjęcie zgotowała lubelskiemu poecie też Polonia amerykańska, której ten osobiście przedstawiał swoją twórczość podczas pobytu w 1977 roku.

Łobodowski utrzymywał stałe relacje z Polonią madrycką. Więcej nawet, był jej ważnym członkiem, wokół którego gromadziło się polonijne towarzystwo. Żył bardzo skromnie, o czym przypomina Grzegorz Bąk, a szerzej pisze w tekście Moje wspomnienia o Józefie Łobodowskim Kazimierz 
Tylko-Dobrzański, wieloletni przyjaciel poety, którego dom stanowił hiszpańską przystań i rodzinę pisarza. Oprócz Łobodowskiego niezwykle istotną funkcję wśród polskiej społeczności w Madrycie pełnił ks. Marian Walorek, rektor Polskiej Misji Katolickiej w Hiszpanii, redaktor biuletynu Polonii w Madrycie „Inter nos”. Jego burzliwe i dramatyczne losy oraz związki z Józefem Łobodowskim opisuje Marek Raczkiewicz w tekście Ksiadz Marian Walorek (1912_ 1988). Śladami rektora Polskiej Misji Katolickiej w Hiszpanii.

Madryckie znajomości, na przykład z Kazimierzem Tylko-Dobrzańskim, Karoliną Babecką, córką Juliusza Babeckiego, szefa Polskiego Czerwonego Krzyża w Madrycie, czy hiszpańskim ambasadorem Polskiego Rządu w Londynie, Józefem Potockim, były niezwykle ważne dla Łobodowskiego podczas życia na emigracji również dlatego, że zastępowały mu rodzinę, z którą kontakt miał dalece utrudniony. Pomoc Czerwonego Krzyża okazała się niezastąpiona w czasie, gdy Łobodowski miał poważne problemy ze zdrowiem, których nabawił się, kiedy w latach 1941-1943 przebywał w katalońskim więzieniu.

W biograficznym kontekście, nakreślonym w tym tomie między innymi przez Grzegorza Bąka, Ninę Taylor-Terlecką, Kazimierza Tylko-Dobrzańskiego czy Elżbietę Wittlin-Lipton, bardziej zrozumiałe wydają się poetycka ścieżka Łobodowskiego, jego inspiracje i artystyczne wybory podejmowane w różnych momentach życia. W początkowej fazie twórczości Łobodowskiego odzywają się - by nigdy nie zamilknąć - inspiracje literaturą rosyjską i kulturą ukraińską, wynikające z pobytu poety $\mathrm{w}$ dzieciństwie $\mathrm{w}$ Rosji, ucieczki przed rewolucją 1917 roku na Kaukaz i zamieszkania tam do 1922 roku. Po wojnie zaś już podczas pobytu na emigracji pisarz wchłaniał przez tłumaczenia i obcowanie z kulturą hiszpańską nowy, iberyjski koloryt, który również oddaje w poezji. Widać to na przykład w wierszu Noc nad Madrytem czy w twórczym przetworzeniu pism mistycznych św. Jana od Krzyża w poemacie Noc gorejąca. Szczególne miejsce w twórczości Łobodowskiego zajmuje Lublin, gdzie uczył się i zadebiutował jako poeta. Miasto to było uprzywilejowane już w jego tomikach przedwojennych. Zwraca na to uwagę Ewa Łoś w tekście "Miasto krzyczącej mtodości” - Lublin w twórczości Józefa Eobodowskiego, pisząc o młodzieńczej krytyce lublinian w poezji artysty, na przykład w Lubelskiej szopce politycznej. Jednak w wierszach pisanych wiele lat później z pozycji dystansu i tęsknoty Lublin przemienił się w wyidealizowaną ziemię młodości, spowitą marzeniem, do której powrót był wielkim pragnieniem poety. Spełniło się ono dopiero po jego śmierci, gdy prochy poety spoczęły na otoczonym lipami cmentarzu, który opisywał w Balladzie lubelskiej.

Zagadnienia typowo literaturoznawcze podejmują w tomie Wojciech Ligęza i Agnieszka Goral, którzy piszą o tematach i języku Łobodowskiego, oraz Alicja Jakubowska-Ożóg i Michał Piętniewicz omawiający konkretne utwory i tomiki poety.

Wojciech Ligęza zwraca szczególną uwagę na rozległość kompetencji kulturowych Łobodowskiego. Pisze o jego wyjątkowym talencie językowym, 
umiejętności poruszania się między wieloma kulturami oraz czerpania z różnorodnych źródeł literackich - polskich, rosyjskich, ukraińskich i hiszpańskich, by wymienić te najważniejsze, choć nie należy zapominać też o tomie Kasydy i gazele, powstałym pod wpływem inspiracji kulturą arabską. Wnikliwa lektura wierszy pozwala badaczowi scharakteryzować ewoluujący w ciagu lat idiom Łobodowskiego, który cechuje się rytmizacją czy inkantacyjnym, niemal magicznym charakterem. Na powtarzające się motywy funeralne zwracają uwagę zarówno Ligęza, jak i Agnieszka Goral. Ta ostatnia szczegółowo zajęła się leksyką Łobodowskiego i zauważyła w niej słownictwo z pól semantycznych pokrywających się w pewnym stopniu z leksyką typową dla Juliusza Słowackiego, którego lubelski poeta wysoko cenił. Specyficznie pojmowana ludowość pojawiała się w jego poezji w formie chłopskich zaśpiewów (najczęściej pochodzenia ukraińskiego, ponieważ polskich piosenek poeta nie znał, o czym pisze Tylko-Dobrzański) czy w chętnie przez poetę używanych neologizmach. Tematyka wiejska i katastrofizm jego wczesnej twórczości umiejscawiają go w polu oddziaływania grupy poetyckiej, z której się wywodził Drugiej Awangardy (awangardy lubelsko-wileńskiej). Warto czytać poezję Łobodowskiego właśnie w tym kontekście, związanym z okresem artystycznego formowania się. Echa tych i innych młodzieńczych afiliacji powtarzają się przez lata w wierszach wydanych już na emigracji, na przykład w dwóch przejmujących, lirycznych epitafiach - Na śmierć Czechowicza oraz Na śmierć Sulamity, w tekście poświęconym pamięci Zuzanny Ginczanki, z którą łączyła go przed wojną bliska znajomość.

W poezji pisanej już w Madrycie odnaleźć można też echa innych znajomości i przyjaźni zawartych przez Łobodowskiego w czasach lubelskich. W jego dorobku znajdujemy wiersze dedykowane imiennie, na przykład Kazimierzowi i Halinie Wierzyńskim. Wyjątkowe miejsce wśród nich ma tomik Pamięci Sulamity, o którym pisze Michał Piętniewicz. Jest on poświęcony wspomnianej wcześniej Zuzannie Ginczance, której pamięć poeta zachował do końca życia. Zbiór ten jest wyjątkowy ze względu na nawiązania do tradycji judeo-chrześcijańskiej połączone z tematami ukraińskimi, co zamyślone zostało jako odpowiedź na tomik Ginczanki Centaury. To jeden z tych zbiorów poetyckich, które czynią nieśmiertelnymi pewne postaci, relacje należące już do przeszłości. Kasydy i gazele mogą być też doskonałym przykładem tego, jak kultura Półwyspu Iberyjskiego przenikała stopniowo estetyczny zmysł Łobodowskiego. Oprócz poezji arabskiej, stanowiącej oczywiste źródło inspiracji tego tomu, wpływ na jego kształt miała też twórczość Federica Garcíi Lorki i ludowych pieśni andaluzyjskich.

Próby poety mierzenia się ze swoim losem emigranta stanowią ważną część twórczości, na co również zwraca uwagę Wojciech Ligęza. Wraz z upływem czasu te wewnętrzne boje przybrały metafizyczną czy nawet religijną formę. W przypadku Łobodowskiego stało się to za sprawą inspiracji mistykami hiszpańskimi, szczególnie postacią św. Jana od Krzyża. Poemat Noc gorejąca, 
o którym pisze Alicja Jakubowska-Ożóg jest przykładem doskonałej znajomości hiszpańskiej literatury i zdolności wejścia z nią w twórczy dialog.

Tom Śladami poety... stanowi bardzo ważną i wartościową próbę syntetycznego przedstawienia postaci Józefa Łobodowskiego szerszemu odbiorcy i niejako przywrócenia go świadomości czytelniczej. Różnorodność tematów podejmowanych $\mathrm{w}$ poszczególnych tekstach oraz wielość ośrodków, z których pochodzą autorzy, pozwoliły uniknąć jednostronnego ujęcia postaci poety. Teksty w języku polskim, hiszpańskim i ukraińskim sprzyjają ożywieniu współpracy ośrodków uniwersyteckich w Polsce i Hiszpanii oraz kontynuowaniu prac nad spuścizną literacką Łobodowskiego w obu tych krajach. Niemniej ta wielość tematów i ujęć sprawia, że trudno sprecyzować temat książki. Jest ona zarówno próbą historycznoliterackiej analizy spuścizny poetyckiej Łobodowskiego, studium wielokulturowych inspiracji i wpływów, którym podlegał (opracowanych z literackiego i antropologiczno-kulturowego punktu widzenia), oraz portretem Polonii madryckiej, z wyszczególnieniem jej najważniejszych postaci i mediów. Każdy z tych tematów mógłby obejmować monografię o podobnej objętości jak omawiany tom. Niezupełnie jasny jest podział zamieszczonych tekstów na trzy części. Nie są one podporządkowane kryterium tematycznemu, mają różną objętość, a brak tytułów poszczególnych działów nie pomaga w odkryciu klucza do tego dość arbitralnego wyodrębnienia części książki.

$\mathrm{Na}$ opracowanie wciąż czeka wiele problemów i tematów związanych z twórczością Łobodowskiego, liczne spośród nich zostały zasygnalizowane $\mathrm{w}$ artykułach opublikowanych w tym tomie. W przyszłości z pewnością warto byłoby przyjrzeć się twórczości Łobodowskiego jako swoistej kontynuacji spuścizny szkoły ukraińskiej, inspiracjom poety programem mistycznym Juliusza Słowackiego czy też kwestii znajomości kultury Al-Andalus i jej obecności w twórczości autora Mare Nostrum.

Niewątpliwie tom może być impulsem do podjęcia dalszych badań nad twórczością własną oraz przekładową poety. Taki też wydaje się jej największy atut i prawdopodobnie również cel, który przyświecał redaktorom. Współpraca między Uniwersytetem Complutense a UCMS wciąż trwa, a jej owocem, poza publikacją książkową, są gościnne wykłady pracowników tych uczelni. W lutym 2017 roku Ewa Łoś wygłosiła na Wydziale Filologicznym Uniwersytetu Complutense wykład dotyczący Józefa Łobodowskiego - należy mieć nadzieję, że ta współpraca przyniesie więcej owoców w postaci prac i publikacji poświęconych temu niesłusznie zapomnianemu pisarzowi. 